\title{
OBSTETRICAL MORBIDITIES IN GENITAL TRACT INFECTIONS.
}

Sapna Singh¹, Manju Nawani², Sanjay Kumar Nigam³, Amit Jha4.

1. Assistant Professor, department of Obstetrics \& Gynaecology, Rama Medical College Hospital \& Research Centre, Mandhana, Kanpur, Uttar Pradesh.

2. Professor, department of Obstetrics \& Gynaecology, Rama Medical College Hospital \& Research Centre, Mandhana, Kanpur, Uttar Pradesh.

3. Professor, Department of Pathology, Rama Medical College Hospital \& Research Centre, Mandhana, Kanpur, Uttar Pradesh.

4. Assistant Professor, Department of Community Medicine, Rama Medical College Hospital \& Research Centre, Mandhana, Kanpur,

\section{CORRESPONDING AUTHOR:}

Dr. Sanjay Kumar Nigam, Department of Pathology, Rama Medical College, Mandhana, Kanpur, Uttar Pradesh- 209217.

Email-sknigam@yahoo.com

ABSTRACT: INTRODUCTION- Sub clinical ascending infections through the lower female genital tract are predominant worldwide. Important morbidities related to poor perinatal outcome both for the mother and for the fetus and new born comprise preterm birth, prelabor rupture of membranes, post partum sepsis and maternal anaemia. In the fetus, sepsis and intrauterine growth retardation are suspected to be the consequences of ascending maternal infection. Both the direct effect of the infection and the maternal immune response contribute to these eventualities. This study was done to identify antenatal women with various genital infections and to know the outcome of pregnancy in presence of these infections. OBJECTIVES- Diagnosis treatment and preventive measures in genital infections in Antenatal period to improve the pregnancy out come. MATERIAL AND METHODS- One thousand women were studied for lower genital tract infection by ELISA KITS for chlamydia trachomatis, hanging drop preparation of vaginal discharge for trichomoniasis and mycelia of candida albicans can be seen by wet mount of vaginal dischage in $10 \% \mathrm{KOH}$. Gardnerella vaginal infection was diagnosed by Amsel's criteria . RESULT-out of thousand women $53 \%$ were positive for single or multiple infections (gp-1), 47\% women had no infection (gp-11) . Labour outcome was studied in 415 antenatal women of gp -1 \&395 antenatal women of gp -11 . In gp-1 51.80\% had no effect ,7.71\% had abortions and $40.48 \%$ had pre term labour and/or PROM .Which was significantly higher than in non infected group. IN INFECTED GROUP-41.92\% neonates had no effect others had some effect in terms of LBW, birth asphyxia, neonatal death \& IUD. Which was significantly higher than in non infected group. $\mathrm{P}=0.00$

CONCLUSION- The study showed significantly higher incidence of obstetrical morbidities in women with lower genital tract infection,since genital infections are the root cause of these obstetrical morbidities so early detection and treatment of these infections is very important to improve obstetrical out come.

KEY WORDS : lower-genital tract infection, obstetrical morbidities., Amsel's criteria . 
INTRODUCTION: Host defence mechanism operate against infections affecting maternal and fetal mortality. Sub clinical ascending infections through the lower female genital tract are predominant world wide. Important morbidities related to poor perinatal outcome both for the mother and for the fetus and new born comprise preterm birth, prelabor rupture of membranes, post partum sepsis and maternal anaemia. In the fetus, sepsis and intrauterine growth retardation are suspected to be the consequences of ascending maternal infection.

In the newborn septicemia and respiratory disorders as well as neurological disorders seem to be consequences of such ascending genital infections in the pregnant women. It is to elucidate the host defence mechanism and antimicrobial barriers from the vagina through the cervix, fetal membrane and amniotic fluid including the early fetal immunocopetence in the second and third trimester of pregnancy.

Preterm labor may occur in 10-20\% of pregnancies in developing countries, whereas prelabor rupture of membranes and post partum septicemia may occur in 5-10\% in such settings. All these in turn are associated with neonatal infections and morbidity. Both the direct effect of the infection and the maternal immune response contribute to these eventualities. ${ }^{1,2}$ systemic infections and genital infections due to many different microorganisms including Chlamydia trachomatis, trichomonas vaginalis and gardnerella vaginalis are reportedly involoved in initiating preterm labor. $2,3,4,5$

This study was done to identify antenatal women with various genital infections and to know the outcome of pregnancy in presence of these infections. The antenatal women attending the outpatient department and admitted in indoor and emergency wards of department of obstetrics and gynaecology, Rama Medical College Hospital and Research Center, Kanpur during two years period (Feb.2010 to Feb.2012) were enrolled in this study. Suspected or confirmed fetal congenital malformation by USG, liver diseases, immunocompromised patient, diabetic patient, concurrent intake of hepatoxic medicines were excluded from the study

MATERIALS AND METHODS: A detailed history regarding personal, social environmental , menstrual and obstetric history was taken, general, obstetrical and gynaecological examination was done . vagina and cervix was examined for presence of inflammation, erosion, ulceration, bleeding and vaginal discharge which was examination for colour, consistency, odour and amount. Apart from routine investigations certain specific investigations were performed when indicated.

Patients serum was analysed by commercially available ELISA KITS (as per manufactures instructions) for Chlamydia trachomatis. (II) hanging drop preparations of vaginal secretions were examined for trichomonas vaginalis. (III) mycelia of candida albicated can be seen by wet mount of vaginal discharge in $10 \% \mathrm{KOH}$. (IV) gardnerella vaginalis infection was diagnosed byAmsel's criteria

RESULTS \& DISCUSSION: Total 1000 patients were taken for study out of which 530 patients were found to be positive for single or combination of infection (group I) , 130 patients found tobe positive for single infection (24.53\%)400 patients found to be positive for multiple infection (75.47\%) 470 patients having no infection (47\%) ( group-II) (table1). Out of 530 patients, Chlamydia trachomatis found to be positive for 342 (64.53\%) patients.3,6,7,8,9,10 trichomonas vaginalis found to be positive for $228(43.01 \%)$ patients ' candida albicans found to be positive for 
$206(38.87 \%)$ patients , gardnerella vaginalis found to be positive for 154 ( $29.05 \%)$ patients (table II). ${ }^{11,12,13,14,15}$

Out of 400 antenatal women of group I, C. trachomatis along with t. vaginalis was found to be positive in $110(27.50 \%)$ women , C. trachomatis along with G. vaginalis was found to be positive in $62(15.50 \%)$ women , T. vaginalis along with G. vaginalis was found to be positive in $42(10.50 \%)$ women, candida albicans along with G. vaginalis was found to be positive in 24(6.0\%) women, C. trachomatis along with candida albicans was found to be positive in 98 (24.50\%) women and T. vaginalis along with candida albicans was found to be positive in $64(16 \%)$ women ( table-III)Out of 530 patients of group I, 115 dod not come for follow -up out of 470 patients of group II, 75 did not come for follow -up.

In the current study, labour outcome was studies in 415 antenatal women of group I and 395 antenatal women of group II . In group I, 215 (51.80\%) had no effect , 32 (7.71\%) had abortions and $168(40.48 \%)$ had preterm labour and /or premature rupture of membranes. In group II 296 (74.94\%.) had no effect,20(5.06\%) had abortions and 79(20\%) had preterm labour and / or premature rupture of membranes. The difference between two groups was found to be statistically significant for unaffected cases in absence of infections and preterm labour and/ or PROM in presence of infections $(p<0.05) p=.0000$ ( table IV). but not found to be statistically significant for abortions in presence of infections $(\mathrm{p}=0.1635$; $\mathrm{p}>0.05)$. study of previous authors also showed the association of various genital infection on adverse pregnancy outcome. ${ }^{16,17,18,19,20,21,22}$

In the present study, neonatal outcome was seen in 415 antenatal women of group I and 395 antenatal women of group II. In group I, 174 (41.92\%) anetenatal women had no effect on neonatal outcome 150 (36.14\%) had low birth weoght babies, 61 (14.70\%) had birth asphyxia $10(2.41 \%)$ had neonatal death and $20(4.82 \%)$ had IUD. In group II, 304(76.96\%) antenatal women had no effect $44(11.14 \%)$ had low birth weight, 31 (7.84\%) had birth asphyxia 6(1.52\%) had neonatal death and $10(2.53 \%)$ had IUD. The difference between two group was found to be statistically significant $(\mathrm{p}<0.05)=.0000($ table $\mathrm{V}) .^{23}$

CONCLUSION :The present study showed the significant association of genital infections with adverse pregnany outcome, as it is also evident in previous similar studies . the observation that histologically apparent amniotic fluid infection are 2-3 folds more common when fetal membrane rupture just after the onset of labour suggests the concept that infection predates PROM

The evidence that amniotic fluid samples from patients with PROM are more frequently colonized with pathogens than are samples from patients without PROM. Fetal infections may develop early in pregnancy to produce obvious stigmas at birth. The incidence of still births and IUDs caused by fetal infection appears to be remarkably consistent.

The study showed significantly higher incidence of obstetrical morbities in women with lower genital tract infection, since genital infections are the root cause of these obstetrical morbidities, early detection and treatment of these infections in very important $t$ o important to improve obstetrical outcome.

\section{REFERENCES:}


1. Chapel , H., Haeney, M., M isbah, S. \& Snowden, N. (1999) pregnency in Essentials of Clinical Immunology (Anderson, e. \& Wilson, A., eds) pp 304-313, 4th edition. Blackwell science Ltd. Oxford, U.K.

2. Gibbs, R.S., Romero, R., Hiller, S.L., Eschenback, D.A. And Sweet, R.L.(1992) . A review of premature birth and subclinical infection . Am. J. Obstet Gynaecol. 166:1515 -1528.

3. Alexander, E.R. \& Harrison, H.R. (1983). Role of chlamydia trachomatis in perinatal infection .Rev. infect. Dis-5:713-719.

4. Swadpanich U, Lumbiganon P, Prasertcharoensook W, Laopaiboon M. Antenatal lower genital tract infection screening and treatment programs for preventing preterm delivery. Cochrane Database of Systematic Reviews 2008, Issue 2. Art. No.: CD006178. DOI: 10.1002/14651858.CD006178.pub2.

5. 5-3 de Louvois J, Hurley R, Stanley V C. Microbial flora of the lower genital tract during pregnancy: relationship to morbidity. J Clin Pathol 1975; 28: 731-5.

6. Manavi K. A review of infection with Clamydia trachomatis. Best Practice \& Research Clinical obstetrics and Gynaecology,. 2006;20(6):941-51.

7. Howie SE, Horner PJ. Chlamydia Trachomatis Infection During Pregnancy - Known Unknowns. Discovery Medicine [serial on the Internet]. 2011; 12(62): Available from: www.discoverymedicine.com.

8. Baud D, Regan L, Greub G. Emerging role of Chlamydia and Chlamydia-like organisms in adverse pregnancy outcomes. Current Opinion in Infectious Diseases. 2008;21:70-5.

9. Bebear C, de Barbeyrac B. Genital Chlamydia trachomatis infections. Clinical Microbiology and Infection. 2009;15:4-10.

10. Ana Berta Canas Posada, Jon Jonasson, Leonar de Linares, Solgun Bygdeman : Prevalence of urogenital chlamydia trachomatis infection in EI Salvador, Infection during pregnancy and perinatal transmission. International Journal of STD and AIDs 1992: 3:33-37.

11. Lossick , J.G. And Kent. H.L. (1991) . Trichomoniasis : trends in diagnosis and management Am. J.Obstet. : Gynaecol. 165:1217-1222.

12. Apea-Kubi KA, Sayi B, Yamaguchi S, Ofori-AdjeiD. Bacterial vaginosis, Candida and Trichomonasvaginalis infection in Antenatal andGynaecological patients in Ghana. TropicalJournalObstetrics and Gynaecology, 2005;22(2):103-107 .

13. Salhan S, Mittal A. Effect of treatment for C. trachomatis during pregnancy. Int J Gynecol Obstet 2003; 80: 129-137.

14. Hurley R, Leask B G S, Faktor J A, Fonseka C I.Incidence and distribution of yeast species and of Trichomonas vaginalis in the vagina of pregnant women.J ObstetGynaecolBrCommonw 1973; 80: 252-7.

15. Hammill HA (2000). Trichomonas vaginalis. J. Obstet. Gynecol., 16(39): 234-236

16. Goldenberg RL, Hauth JJC, Andrews WW. Intrauterine infection and preterm delivery. N Engl J Med 2000; 342: 1500-1507.

17. Klebanoff MA, Hillier SL, Nugent RP, et al. Is bacterial vaginosis a stronger riskfactor for preterm delivery when it is diagnosed earlier in gestation? Am J Obstet Gynecol 2005; 193 : 470-477. 
18. Eschenbach DA, Hillier S, Critchoer C (1999). Diagnosis and Clinical manifestation of bacterial vaginosis. J. Obstet. Gynecol., 16 (8): 178.

19. Namkinga LA, Matee MIN, Kivaisi AK, Moshiro C. Prevalence and risk factors for vaginalCandidiasis among women seeking primary care for genital infections in Dares Salaam Tanzania.East African Medical Journal 2005; 82(3):139-144.

20. Gravett M, Nelson H , DeRough $\mathrm{T}$ et al : Independent assosiation of bacterial vaginosis and chlamydia trachomatis infection with adverse pregnancy outcome.JAMA 1986; 256: 18991903.

21. Govender, Hoosen Moodely et al : Bacterial vaginosis and assosiated infections in pregnancy . International Journal of Gynaecology and obstetrics, 55,1996; 23-38.

22. Sweet RL, Landers DV, Walker C, Schachter J. ; Am. J. Obstet Gynaecol 1987 Apr.: 156 (4) : 824-33.

23. Wasserheit JN, Holmer KK: Reproductive tract infections. P.7 plenum press, New York 1992.

Table I: Distribution of total antenatal women in according to presence and absence of genital infections:

\begin{tabular}{|l|c|c|}
\hline Women having infections & Number & Percentage \\
\hline $\begin{array}{l}\text { Group 1 (Positive for } \\
\text { infections) }\end{array}$ & $\begin{array}{c}530 \\
\text { (With single infection-130) } \\
\text { (With multiple infection-400) }\end{array}$ & $53.00 \%$ \\
\hline $\begin{array}{l}\text { Group 11 (Negative for } \\
\text { infections) }\end{array}$ & 470 & $47.00 \%$ \\
\hline Total & 1000 & $100.00 \%$ \\
\hline
\end{tabular}

Table II: Distribution of antenatal women in group I according to presence and absence of various organisms:

\begin{tabular}{|l|l|l|}
\hline Micro Organism & \multicolumn{1}{|c|}{ Number } & Percentage \\
\hline Chlamydia trachomatis & 342 & $64.53 \%$ \\
\hline Trichomonas vaginalis & 228 & $43.01 \%$ \\
\hline Candida albicans & 206 & $38.87 \%$ \\
\hline Gardneralla vaginalis & 154 & $29.05 \%$ \\
\hline
\end{tabular}

Table III: Distribution of antenatal women in group I according to presence of combination of infection.

\begin{tabular}{|l|l|l|}
\hline Combination of Micro Organism & Number & Percentage \\
\hline C. Trachomatis + T. Vaginalis & 110 & $27.50 \%$ \\
\hline C. Trachomatis + G. Vaginalis & 62 & $15.50 \%$ \\
\hline T. Vaginalis + G. Vaginalis & 42 & $10.50 \%$ \\
\hline Candida + G. Vaginalis & 24 & $6.00 \%$ \\
\hline C. Trachomatis + Candida & 98 & $24.50 \%$ \\
\hline T. Vaginalis + Candida & 64 & $16.00 \%$ \\
\hline Total & 400 & $100.00 \%$ \\
\hline
\end{tabular}




\section{ORIGINAL ARTICLE}

Table IV: Distribution of antenatal women in group I and group II according to pregenecy outcome due to presence of genital of infection.

\begin{tabular}{|l|l|l|l|l|c|}
\hline Outcome of Labour & $\begin{array}{l}\text { Group } \\
\text { I }\end{array}$ & $\begin{array}{l}\text { Group } \\
\text { II }\end{array}$ & & P value \\
\hline & No. & $\%$ & No. & $\%$ & \\
\hline Unaffected & 215 & $51.80 \%$ & 296 & $74.94 \%$ & 0 \\
\hline Abortions & 32 & $7.71 \%$ & 20 & $5.06 \%$ & 0.16 \\
\hline $\begin{array}{l}\text { Preterm Labour and / or premature repture of } \\
\text { membranes }\end{array}$ & 168 & $40.48 \%$ & 79 & $20.00 \%$ & 0 \\
\hline Total & 415 & $100.00 \%$ & 395 & $100.00 \%$ & \\
\hline
\end{tabular}

$P$ value $x 2=47.21, \mathrm{df}=2, \mathrm{P}=0.0000 ; \mathrm{p}<0.05$

Table V: Distribution of antenatal women in group I and group II according to neonatal outcome due to presence of genital infection;

\begin{tabular}{|l|l|l|l|l|l|}
\hline Outcome of Labour & Group I & & Group II & & P value \\
\hline & No. & $\%$ & No. & $\%$ & \\
\hline No. effect & 174 & $41.92 \%$ & 304 & $76.96 \%$ & \\
\hline Birth asphyxia & 61 & $14.70 \%$ & 31 & $7.84 \%$ & \\
\hline Neonatal death & 10 & $2.41 \%$ & 6 & $1.52 \%$ & \\
\hline LBW & 150 & $36.14 \%$ & 44 & $11.14 \%$ & \\
\hline IUD & 20 & $4.82 \%$ & 10 & $2.53 \%$ & \\
\hline Total & 415 & $100.00 \%$ & 395 & $100.00 \%$ & \\
\hline
\end{tabular}

$P$ value $x 2=106.96, \mathrm{df}=4, \mathrm{P}<0.0000: \mathrm{P}<0.05$ 


\section{ORIGINAL ARTICLE}
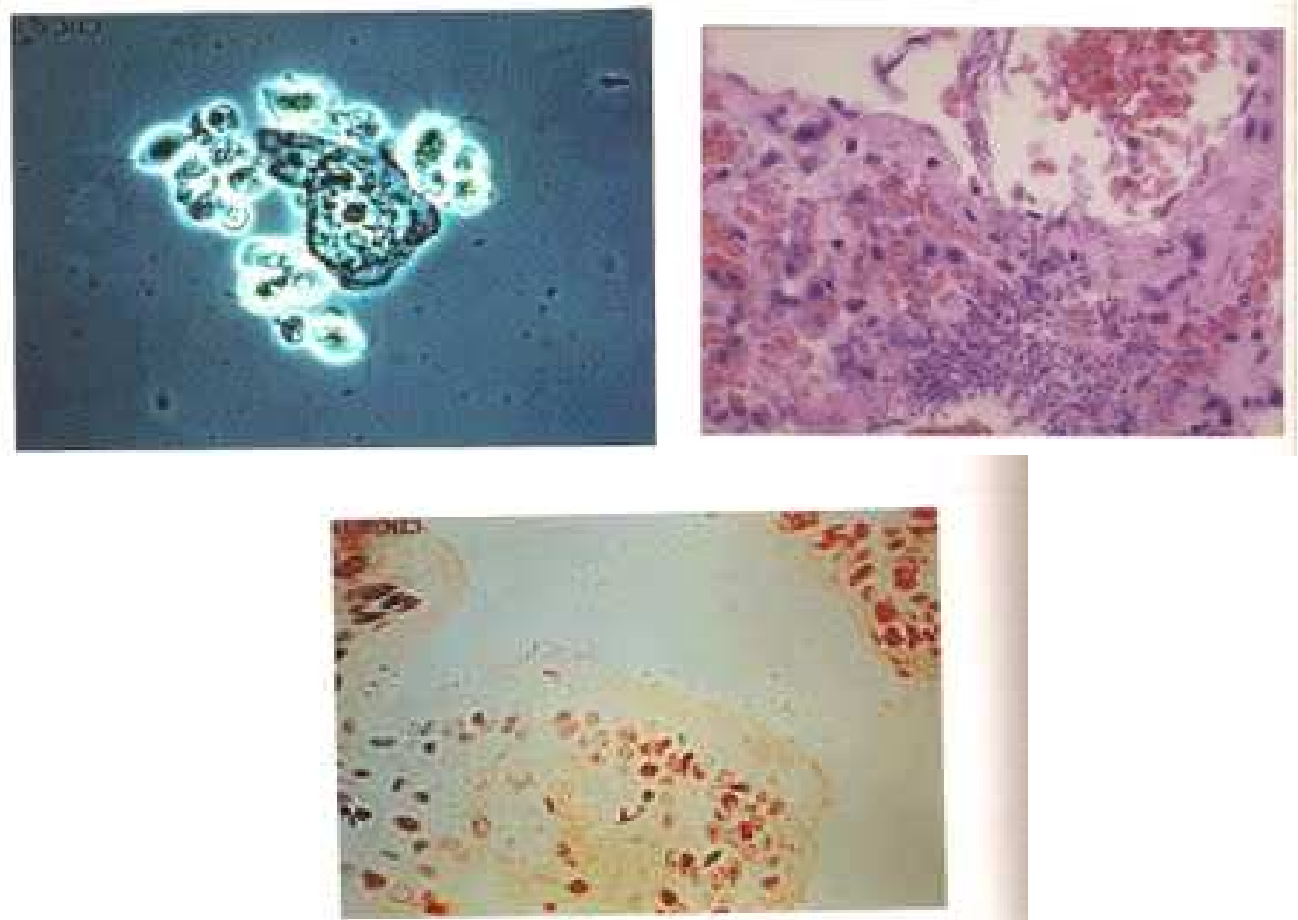

TRICHOMONAS VAGINALIS

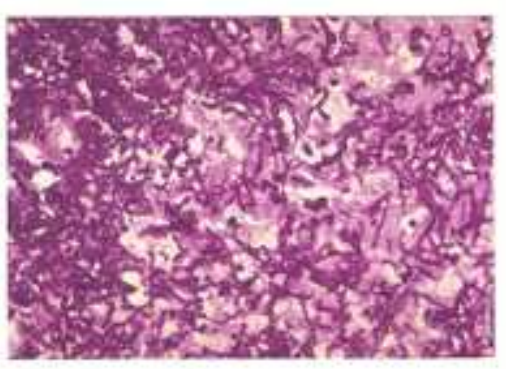

FUNGAL MYCELIA
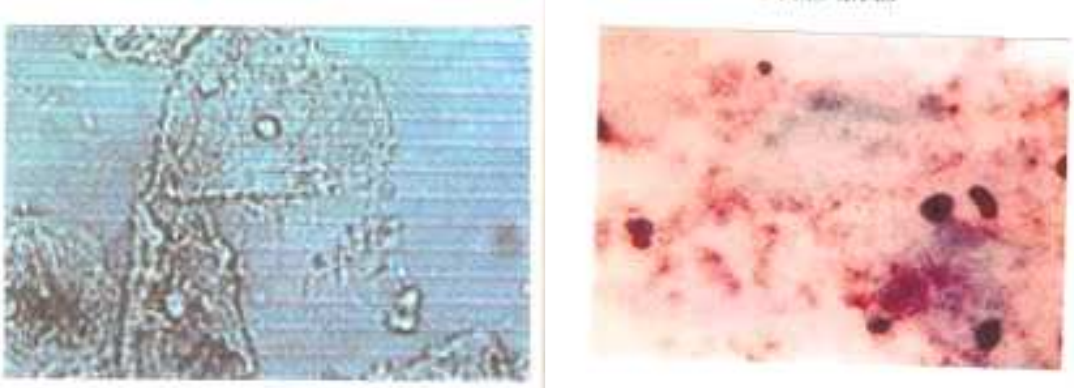

CLUE CELLS: This study was conducted with an objective to know the prevalence of genital injection in pregnant women and the outcome of pregnancy affected by these infections..$^{4,5}$ 